\title{
Adaptive Gas Path Modeling in Gas Turbine Health Monitoring
}

\author{
E. A. Ogbonnaya ${ }^{1}$, K. T. Johnson ${ }^{1}$, H. U. Ugwu' ${ }^{2}$, \\ C. A. N. Johnson ${ }^{3}$ and Barugu Peter Forsman ${ }^{4}$ \\ ${ }^{1}$ Department of Marine Engineering, Rivers State University of Science and Technology, \\ Port Harcourt \\ ${ }^{2}$ Department of Mechanical Engineering, Michael Okpara University of Agriculture, \\ Umudike-Umuahia \\ ${ }^{3}$ Department of Marine Engineering, Niger Delta University, Wilberforce Island, \\ Bayelsa State \\ ${ }^{4}$ Department of Welding, Oil and Gas Engineering, Petroleum Training Institute, \\ Effurun, Delta State \\ Nigeria
}

\section{Introduction}

The ability to model the behavior of gas turbines (GTs) is critical in all aspects of energy and power generation engineering. A computerized approach giving the possibility for a more detailed gas path component fault diagnosis and prognosis using the MVR is presented. A diagnostic engine performance model is the main tool that points to the faulty engine component. The diagnostic component model was also used to come up with the software code-named Thermodynamics and Performance Condition Monitoring( THAPCOM) written in $\mathrm{C}++$ programming language to effectively identify the fault on the engine. Several scheduled visits were thus made to AFAM IV, GT 18, TYPE 13D power plant located near Port Harcourt, in Rivers State of Nigeria. Continuous and periodic monitoring of the thermodynamics/performance parameters such as temperature, pressure, air pumping capability, rotational speed, air, fuel and gas flow were carried out. This exercise lasted for a period of three months on hourly basis to predict the health of the engine. When these data were analyzed by the software, the following results were obtained $\frac{\Delta A_{N}}{A_{N}}=1.4598 \mathrm{e}^{-0.008}$, $\frac{\Delta n_{c}}{n_{c}}=1.6630 \mathrm{e}^{-0.007}, \quad \frac{\Delta T_{c}}{T_{c}}=1.1626 \mathrm{e}^{-0.008}$ and $\frac{\Delta T_{3 c}}{T_{3 c}}=7.5508 \mathrm{e}^{-0.007}$, which correspond to average overall efficiency of $27.3 \%$ and active load of $48 \mathrm{MW}$. These were indications that the test engine had suffered from fouling, degraded compressor performance and seal leakage. THAPCOM gives an alarm signal when a set limit is exceeded so that maintenance could be scheduled.

Nomenclature and Abbreviation:

$A=$ Actual value

$A_{L}=$ Active load $(M W)$

$A_{N}=$ Area of nozzle $\left(\mathrm{m}^{2}\right)$ 


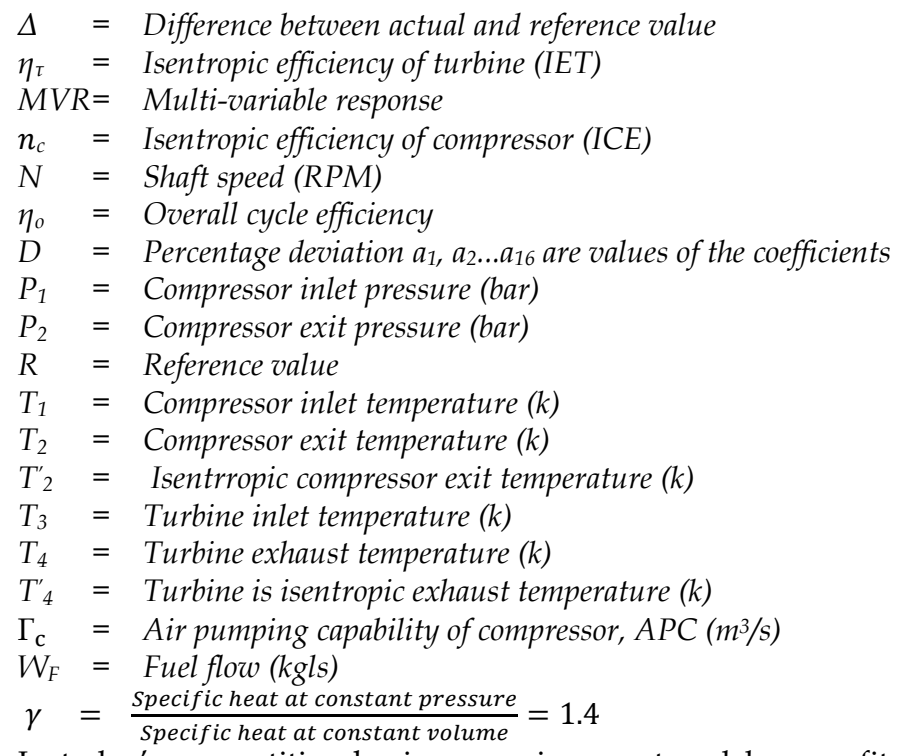

In today's competitive business environment and low profit margins, manufacturers are faced with the growing production demands while cutting the cost of manufacturing (Bell, 2003). One pervasive cost that drags down productivity is the unplanned equipment and manufacturing down time. High performance turbo machines especially GTs are now extremely important elements of industries. Some areas where GTs are used include electric power, petrochemical, mining, marine, air craft, onshore and offshore oil and gas industries. (Ogbonnaya (2004a), Ogbonnaya (2004b), Pussey (2007), Brun and Kurz (2007), Rieger, et al, (1990), Ogbonnaya (2009), Ogbonnaya and Theophilus-Johnson (2010), Loboda and Yepifanov (2010), Aretakis, et al, (2010)). This chapter is therefore timely for these maritime organisations to adopt the proactive measures being proferred to prevent their equipment from catastrophic downtime. While running, GTs are adversely affected by the environmental factors such as dust particles, smoke, smog, oil mist and high humidity (Brun and Kurz (2007), Schneider, et al, (2009), Ogbonnaya and Theophilus-Johnson (2010)). These factors have resulted to degradation mechanisms of fouling, erosion, corrosion and abrasion which reduce the overall performance of the aerodynamic components of the plant (Brun and Kurz (2007), Schneider, et al, (2009), Ogbonnaya and Theophilus-Johnson (2010)).

The use of performance engine models in diagnostics has been initiated since the early 70's. The first approaches were based on linearized models (Aretakis, et al, 2010) while Stamatis, et al., (1991), introduced the concept of using directly non-linear models in diagnostics. Also, methodological steps of simulation and modeling used by Maria (1997), Erbes, et al., (1993), Erbes and Palmer (1994) and Ogbonnaya (2004a) proved that modeling and simulation are handy tools for condition monitoring.

The gas path analysis technique gives the possibility to identify the amount of deterioration of individual components and assess its effect on overall performance providing information, which is valuable for improving cost effectiveness of maintenance actions. An analytical tool that can be used for this purpose was presented in Doel (1994). Performance diagnostic methods for identifying deterioration has also been presented by Urban and Volponi (1992) and Volponi (1994). These approaches show which component is malfunctioning and depending on the established experience, can offer an evaluation of the 
nature of malfunction. The compressor and turbine deterioration are the main cause of the overall performance deterioration. The introduction of measured gas path variables such as pressure, temperature, rotational speed, fuel flow, air flow, gas flow etc is hereby consolidated through this project.

The gas path components, such as compressors, turbines and combustion chamber can be affected by foreign object damage, fouling, tip rubs, seal wear and erosion. The ability to identify the faulty component and simultaneously diagnose the defect with its consequences is another purpose of this chapter. It also allows the operator to take necessary maintenance measures to rectify the fault and provide an assessment of the GTs life cycle and valuable data for prognostics and condition based maintenance scheduling. To achieve these, a detailed component diagnostic modeling needs to be applied. Therefore, the technology of prognosis is recommended in this work because it involves diagnosis, condition and failure model. Prevention of catastrophic and unexpected downtime was thoroughly considered to come up with the software called "THAPCOM" written in C++ programming language to diagnose and prognose the health of the GT. Trend monitoring technique was applied using multiple variable mathematical models (MCMV) in matrix form (Bently et al., 2002). The introduction of "THAPCOM" into GT diagnosis and prognosis conforms to the use of thermodynamics / performance parameters (dependent and independent parameters) as it is the driving force of the GT. "THAPCOM" stands for THermodynamics And Performance COndition Monitoring. As stated in Uhumnwangho, et al., (2003), Brun and Kurz (2007) and Ogbonnaya (2009), the deviation of GT thermodynamics and performance parametric values from their reference values stated in the manufacturer's manual is an indication of impending failure. This is because condition monitoring is the process of ascertaining the state of a parameter in an equipment such that any adverse significant deviation/change is an indication of impending failure.

\subsection{Approaches to monitoring and data collection}

Recently, continuous and periodic monitoring are used for GT data collections. Although, the presence of continuous monitoring does not eliminate the need for periodic monitoring (Guy, 1995), the continuous monitoring system warns the operator about imminent problems. Periodic monitoring along with the collection of external data provides a means for analysis and projection of potential long-term problem with respect to maintenance and operation (Ogbonnaya and Theophilus-Johnson, 2010). The collection of GT model data is capable of acquiring the necessary information to monitor and trend the engine health. This present work also utilized periodic monitoring to achieve its aim.

\subsection{Brief condition monitoring methods}

The already known novel methods of gas path model-based component condition monitoring used by Ogbonnaya $(1998,2004 a)$ is integrated into the THAPCOM. The works of Loboda and Yepifanov, (2010); Donald, et al, (2008); Loboda, (2008); Fast, et al., (2009); Aretakis, et al; (2003); Romesis and Mathioudakis, (2003); Roemer and Kacprzynski, (2000); Volponi, et al., (2003); Kamboukous and Mathioudakis, (2005) on gas path analysis in condition monitoring, were also critically considered to actualize this task. More so, trend monitoring as utilized in Bently, et al., (2002) and Uhumnwangho, et al., (2003) was also seen as a viable tool for this package. Finally, the benefits of motor condition monitoring (MCM) in Bell (2003); Pussey (2007) were rigorously brought to bear to bring this present research to fruition. In most of these works, as well as Ogbonnaya and Koumako (2006), 
operational safety and control of the GT engines were equally harnessed in this new technology.

\subsection{The software "THAPCOM"}

THAPCOM is a viable diagnostic tool because it is capable of providing early warning to progressively indicate imminent fault during engine operation. It analyses conditions to prevent unplanned down time. THAPCOM is an inexpensive diagnostic tool that gives accurate maintenance decision information which is understandable to both low and semiskilled personnel. Therefore, it also eliminates the short-comings of both performance and trend monitoring. Their similarity is that they all measure pressure, flow temperature and rotational speed simultaneously. The plus of THAPCOM is that it relates deterioration to consequences. THAPCOM uses model-based fault detection and diagnostic techniques (Ogbonnaya and Theophilus-Johnson (2011). This relates the deterioration which the engine has undergone to consequences along the gas path of a GT engine. When THAPCOM is interfaced with a GT, it first studies the system for a period of time through acquiring and processing the real-time data from the engine. The data is processed using system identification algorithms for both the actual (operational) behavior to the reference (design) behavior of the engine.

THAPCOM stores the processed data in its internal data base and also serves as the reference (design) values. These reference values are usually mean values of the performance parameters during factory test. During the monitoring session, THAPCOM processes the acquired engine data and compares the results with the data stored in its internal database. If the results obtained from the acquired data are significantly different from the reference values, THAPCOM indicates a faulty level through a series of alarm signal. The level is determined by the magnitude of their percentage deviation when compared. THAPCOM monitors, compares 15 thermodynamics and performance parameters and uses 4 of the parameters to obtain the coefficients. THAPCOM is similar to MCM, ANNs used in Ogbonnaya (2004a and 2009) in their mode of operation but their difference is that MCM measures only current and voltage while THAPCOM measures thermodynamics and performance parameters. ANNs was used to diagnose and prognose GT rotor shaft faults. THAPCOM displays the most sensitive performance parameters of the engine such as those which are used for diagnostics and prognostics. It is an advancement of the component model-based condition monitoring for a GT engine (Ogbonnaya et al, 2010).

\section{Multi variable mathematical modeling}

The approach used in this research is trend monitoring as MVR in matrix form. Data were obtained both statistically and analytically and constitute the most sensitive thermodynamics and performance parameters at the various components of the engine. Data were collected on hourly basis, for a period of three months from an operational GT plant used for electric power generation. The data were sampled and the mean taken for weekly basis. The GT is a $75 \mathrm{MW}$ plant. This technique is in accordance with the methods stated in subsection (1.2). For instance, the method of model-based computer program yielded accurate results than the manual method. The method of model-based computer programming is faster in diagnosing faults. This use of computer program approach, signals the limit of operation through instrumentation in the form of alarm (Baker, 1991; Bergman, et al, 1993; Stamatis et al, 2001; Alexious and Mathioudakis, 2006; Ogbonnaya et al, 2010). This present work would contribute solution to the unexpected failure/down time of GTs 
by giving timely alarm signals. The deviations of the thermodynamics and performance parameters when the actual values were compared to their reference values will be used to analyze the MVMMs to diagnose and prognosis the health of the GT. The data collected from the test engine was obtained using the following model thermodynamics equations. It was assumed that $\mathrm{P}_{1}=\mathrm{P}_{4}$ and $\mathrm{P}_{2}=\mathrm{P}_{3}$.

Isentropic compression of the compressor was obtained as follows:

$$
\frac{T_{2}^{\prime}}{\mathrm{T}_{1}}=\left(\frac{P_{2}}{P_{1}}\right)^{\frac{\gamma-1}{\gamma}}
$$

Similarly, isentropic expansion of the turbine was obtained as follows:

$$
\frac{\mathrm{T}_{3}}{T^{\prime}{ }_{4}}=\left(\frac{P_{3}}{P_{4}}\right)^{\frac{\gamma-1}{\gamma}}
$$

Isentropic efficiency of compressor $=\quad \frac{\text { Isentropic Enthalpy Drop }}{\text { Actual Enthalpy Drop }}$

$$
\eta_{\mathrm{c}}=\frac{\tau_{2^{1}}-\tau_{1}}{\tau_{2}-\tau_{1}}
$$

Isentropic efficiency of turbine $\quad=\quad \frac{\text { ActualEnthalpy Drop }}{\text { Isentropic Enthalpy Drop }}$

$$
\eta_{\tau}=\frac{T_{3}-T_{4}}{T_{2}-T_{4}^{\prime}}
$$

While the following model deviation equations were applied

$$
\begin{gathered}
\frac{\Delta T_{3}}{T_{3}}=\frac{T_{3 A}-T_{3 R}}{T_{3 R}} \\
\frac{\Delta N}{N}=\frac{N_{A}-N_{R}}{N_{R}} \\
\frac{\Delta \eta_{C}}{\eta_{C}}=\frac{\eta_{C A}-\eta_{C R}}{\eta_{C R}} \\
\frac{\Delta \Gamma_{C}}{\Gamma_{C}}=\frac{\Gamma_{C A}-\Gamma_{C R}}{\Gamma_{C R}}
\end{gathered}
$$

The parameters in Equations (5) to (8) are the independent variables in the MVMMs. These equations were used to generate the coefficients $a_{1}$ to $a_{16}$ in the MVMMs. $a_{1}$ to $a_{16}$ are expressed as functions of:

$$
\begin{aligned}
& \left.\frac{\Delta T_{3}}{T_{3}}=f\left[a_{1}, a_{5}, a_{9}, a_{13}\right]\right) \\
& \frac{\Delta N}{N}=g\left[a_{2}, a_{6}, a_{10}, a_{14}\right] \\
& \left.\frac{\Delta \eta_{C}}{\eta_{C}}=h\left[a_{3}, a_{7}, a_{11}, a_{15}\right]\right\} \\
& \left.\frac{\Delta \Gamma_{C}}{\Gamma_{C}}=i\left[a_{4}, a_{8}, a_{12}, a_{16}\right]\right)
\end{aligned}
$$




$$
\mathrm{f}, \mathrm{g}, \mathrm{h}, \mathrm{i}=\mathrm{F}_{\mathrm{n}} \text { Parameters }
$$

The significance of this approach is based on the interface between the components of air and gas path. This approach considered the analysis in terms of the measurable dependent data and the independent performance parameters calculated by a mathematical model based on engine thermodynamics.

\section{Dependent and independent variables}

The independent and dependent parameters represent the variables in various engine components thermodynamics relationship such as the compressor, combustor and turbine units (Bently, et al., 2002). The differential and manipulation of these equations allow the derivation of a general relationship between each change in a dependent parameter and its resulting effects on each independent parameter in turn with all other variables held constant. A matrix was formed using these coefficient relationships by superposition of the independent variable on each independent parameter. The independent parameters are $\mathrm{T}_{3}$, $\mathrm{N}, \eta_{C}$, and $\Gamma_{C}$, while the dependent parameters are $\mathrm{P}_{2}, \mathrm{~T}_{2} \mathrm{~W}_{\mathrm{F}}$ and $\mathrm{A}_{\mathrm{n}}$. A combination of the MVMMs constitute a $4 \times 4$ matrix in which the variables are related by the constant coefficients $\mathrm{a}_{1}$ to $\mathrm{a}_{16}$. This matrix was evaluated as a $4 \times 3$ matrix holding the speed constant in turn to generate each independent parameter change (Bentley, et al., 2002). This is shown in equation (11).

\section{The flowchart for the simulation}

By substituting equation (12) into (14), $\frac{\Delta A_{N}}{A_{N}}$ can be obtained. Equations (5) to (8) and (14) were used for the simulation of THAPCOM in $\mathrm{C}^{++}$programming language to proactively monitor the health of the GT. The flowchart drawn from these equations is presented in figure 1. It is from this flowchart that a computer program in $\mathrm{C}^{++}$used to actualise the work is written. The most salient feature of THAPCOM flowchart and program is that it has two subroutines for ease of manipulation.

The input subroutine in the flowchart helped to store values of $T_{1}, T_{2}, P_{1}, P_{2}, T_{3}, N, T_{4}, \Gamma_{C}, W_{F}$ and $\mathrm{L}$. These values were later returned in subsequent parts of the program where they were needed and used to compute $\frac{\Delta T_{3}}{T_{3}}, \frac{\Delta \eta_{C}}{\eta_{C}}$ and $\frac{\Delta \Gamma_{C}}{\Gamma_{C}}$. This was done after individual values of $\eta_{T}, \eta_{C}, \eta_{0} \ldots$ were computed.

$$
\left.\begin{array}{ccccc} 
& \frac{\Delta T_{3}}{T_{3}} & \frac{\Delta N}{N} & \frac{\Delta \eta_{C}}{\eta_{C}} & \frac{\Delta \Gamma_{C}}{\Gamma_{C}} \\
\frac{\Delta P_{2}}{P_{2}} & a_{1}, & a_{2}, & a_{3}, & a_{4} \\
\frac{\Delta T_{2}}{T_{2}} & a_{5}, & a_{6}, & a_{7}, & a_{8} \\
\frac{\Delta W_{F}}{W_{F}} & a_{9}, & a_{10}, & a_{11}, & a_{12} \\
\frac{\Delta A_{N}}{A_{N}} & a_{13}, & a_{14}, & a_{15}, & a_{16}
\end{array}\right\}
$$




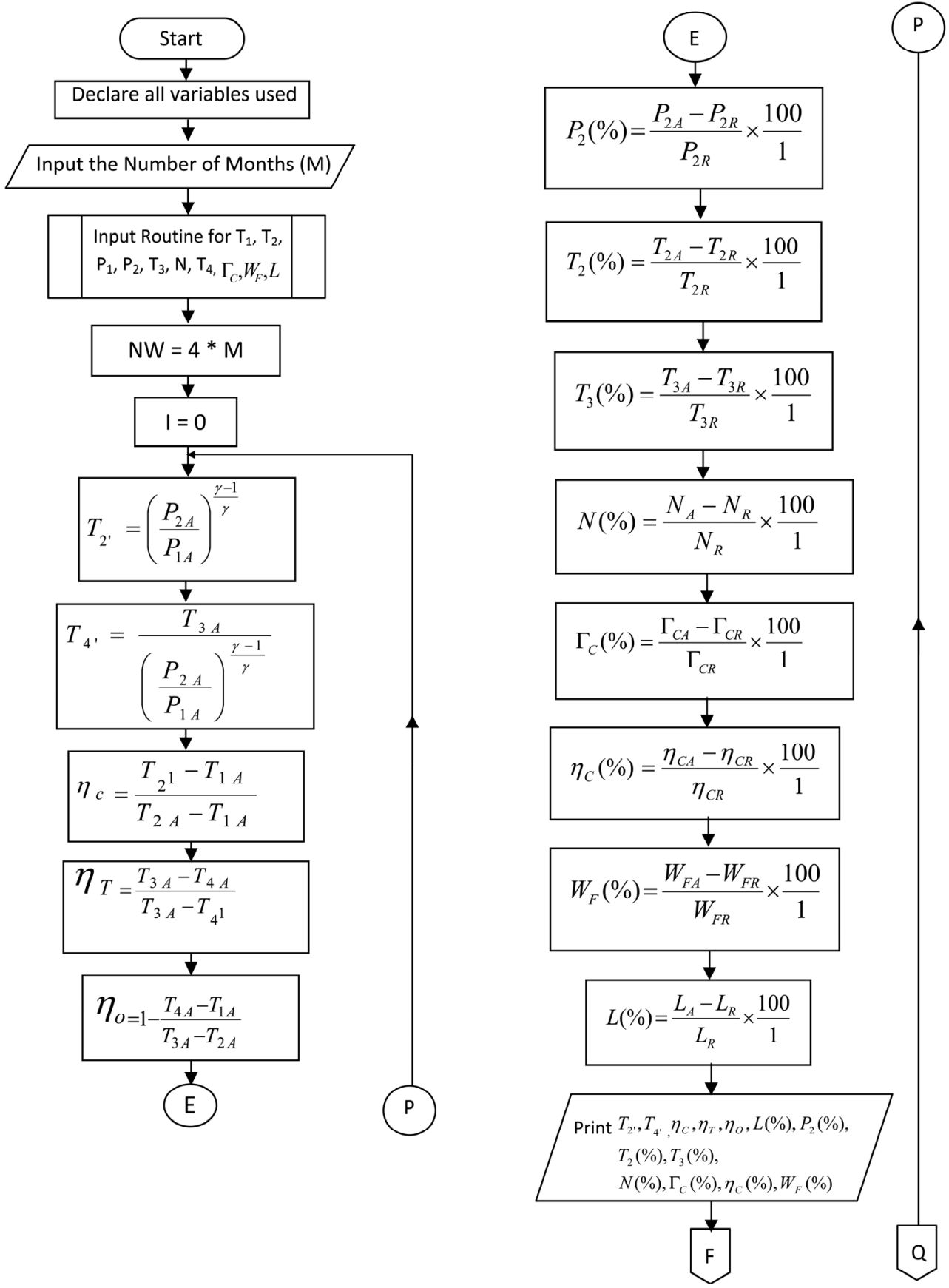

Fig. 1. Flowchart used to develop the computer program to actualize the gas path analysis 


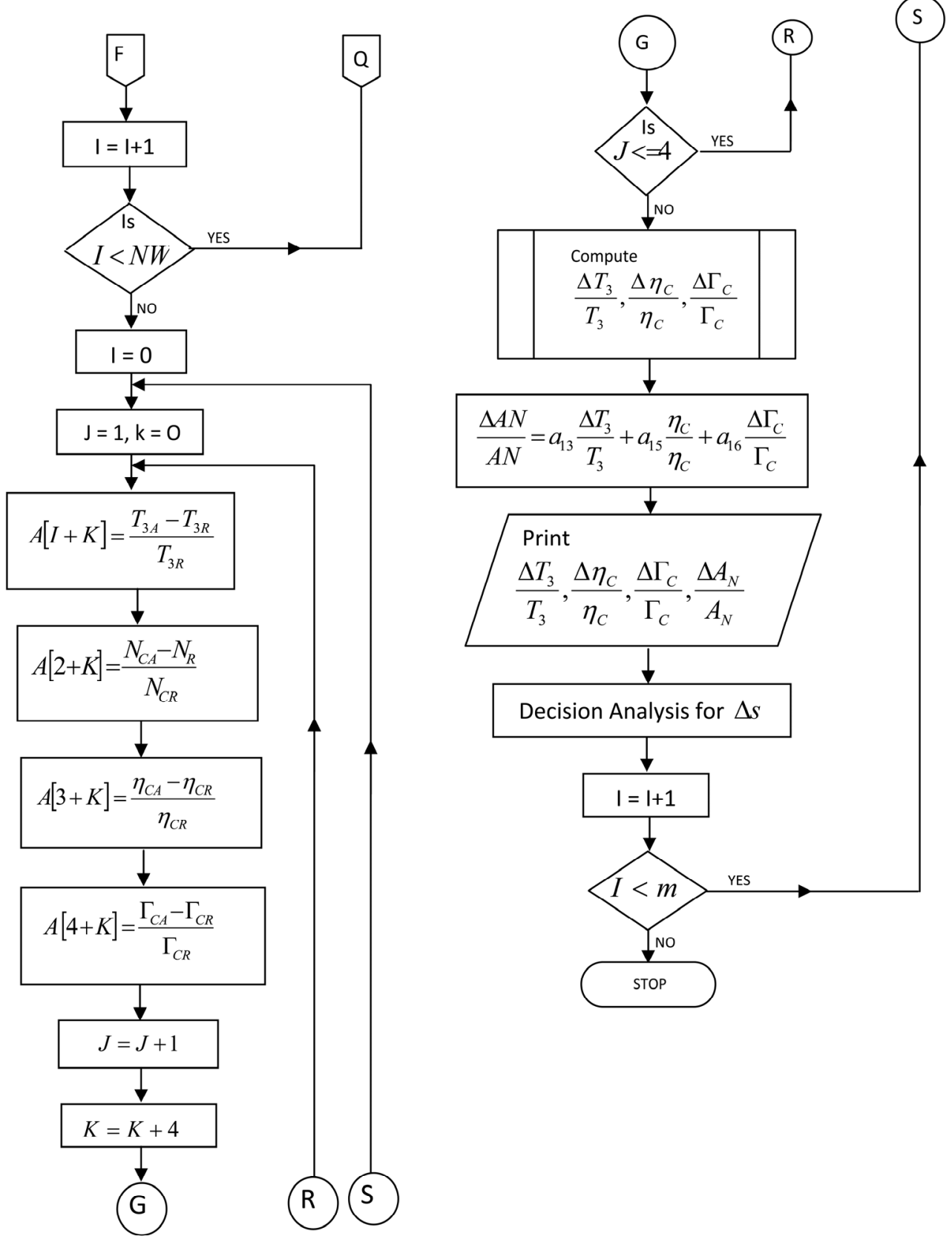

Fig. 1. Continued 
The independent parameters are evaluated as follows:

$$
\begin{aligned}
\frac{\Delta T_{3}}{T_{3}} & =\left|\begin{array}{llr}
a_{2}, & a_{3}, & a_{4} \\
a_{6}, & a_{7}, & a_{8} \\
a_{10}, & a_{11}, & a_{12} \\
a_{14}, & a_{15}, & a_{16}
\end{array}\right| \\
\frac{\Delta \eta_{C}}{\eta_{C}} & \left.=\left|\begin{array}{llr}
a_{1}, & a_{2}, & a_{4} \\
a_{5}, & a_{6}, & a_{8} \\
a_{9}, & a_{16}, & a_{12} \\
a_{13}, & a_{14}, & a_{16}
\end{array}\right|\right\} \\
\frac{\Delta \Gamma_{C}}{\Gamma_{C}} & =\left|\begin{array}{lll}
a_{1}, & a_{2}, & a_{3} \\
a_{5}, & a_{6}, & a_{7} \\
a_{9}, & a_{10}, & a_{11} \\
a_{13}, & a_{14}, & a_{15}
\end{array}\right|
\end{aligned}
$$

Equations (11) and (12) show how the dependent variables were obtained:

$$
\left.\begin{array}{c}
\frac{\Delta P_{2}}{P_{2}}=a_{1} \frac{\Delta T_{3}}{T_{3}}+a_{3} \frac{\Delta \eta_{C}}{\eta_{C}}+a_{4} \frac{\Delta \Gamma_{C}}{\Gamma_{C}} \\
\frac{\Delta T_{2}}{T_{2}}=a_{5} \frac{\Delta T_{3}}{T_{3}}+a_{7} \frac{\Delta \eta_{C}}{\eta_{C}}+a_{8} \frac{\Delta \Gamma_{C}}{\Gamma_{C}} \\
\frac{\Delta W_{F}}{W_{F}}=a_{9} \frac{\Delta T_{3}}{T_{3}}+a_{11} \frac{\Delta \eta_{C}}{\eta_{C}}+a_{12} \frac{\Delta \Gamma_{C}}{\Gamma_{C}}
\end{array}\right\}
$$

With a view to actualize MVMMs, the data shown in tables $1(\mathrm{a})$ and (b) were collected from the operational GT plant. Figures 2 and 3 are the graphs of percentage deviation in $\mathrm{P}_{2}$ and $T_{2}$ against date in weeks while a combined graph of percentage deviation in $P_{2}, T_{2}, \Gamma_{C}$ and $T_{3}$ are shown in figure 4.

\section{Implementation}

The coefficients of each performance parameters are depicted in equation (9) in relation to equations (5) to (8), when the actual value is compared to the reference value. When these coefficients are used with the MVMMs, to diagnose and prognose the GT faults, its state of health was made known. If, while trending its health using equations (12) and (14), and all the $\Delta s=0$, with no performance change, then the GT is said to be healthy.

When $\frac{\Delta A_{N}}{A_{N}}=0, \frac{\Delta \eta_{C}}{\eta_{C}}$ and $\frac{\Delta \Gamma_{c}}{\Gamma_{C}}$ are downward and $\frac{\Delta T_{3}}{T_{3}}$ is upward, it implies degraded compressor. This is an indication of built up dirt, foreign object damage, blade erosion, missing blade, warped blade or seal leakage. The results of the simulation show that $\frac{\Delta A_{N}}{A_{N}}=$ $1.4598 \mathrm{e}^{-0.008}, \frac{\Delta n_{c}}{n_{c}}=1.6630 \mathrm{e}^{-0.007}, \frac{\Delta \Gamma_{c}}{\Gamma_{c}}=1.1626 \mathrm{e}^{-0.008}$ and $\frac{\Delta T_{3 c}}{T_{3 c}}=7.5508 \mathrm{e}^{-0.007}$ for the first four weeks, since THAPCOM analyses data on cumulative basis. This showed that the GT had suffered from fouling, degraded compressor performance and seal leakage. Furthermore, figures 2 and 3 show the graphs of percentage deviation in compressor outlet pressure and 
temperature against date in weeks respectively. The table of values shows that the trajectories depict a sinusoidal trend. This is as a result of fouling, which is known for the reduction in compressor exit pressure from its design value. Figure 4 is a combined plot of $P_{2}, T_{2}, T_{3}, N, \Gamma_{C}, \eta_{C}$ and $A_{L}$ against date in weeks. It shows that, $A_{L}$ suffered the highest deviation. Moreover figures 5, 6 and 7 show the path of percentage deviation in ICE, $A_{L}$ and APC against date in weeks. The sinusoidal trend also means that compressor instabilities were setting in.

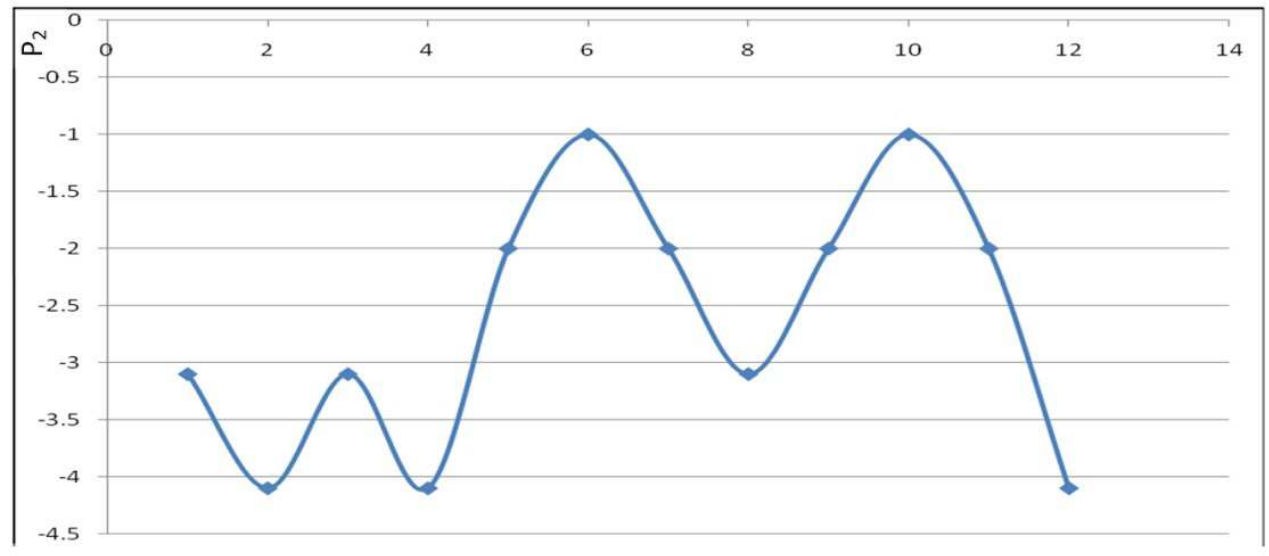

Date (in zoeks)

Fig. 2. Percentage Deviation in $\mathrm{P}_{2}$ against Date (in Weeks)

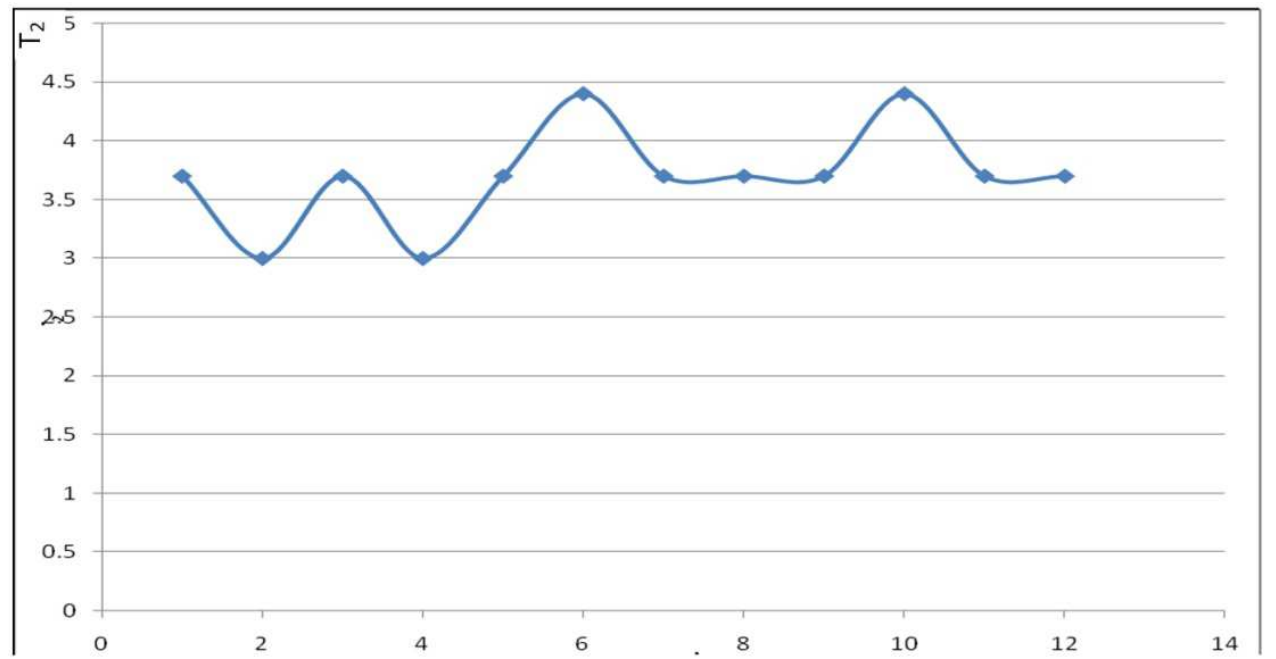

Date (in weeks)

Fig. 3. Percentage deviation in $\mathrm{T}_{2}$ against date (in weeks) 


\begin{tabular}{|c|c|c|c|c|c|}
\hline \multirow{3}{*}{$\sum_{\sum}^{\sum}$} & $\frac{8}{2}$ & $\begin{array}{l}8 \\
\text { ᄋे } \\
\text { p. }\end{array}$ & $\begin{array}{l}\hat{\sigma} \\
\text { ஸे }\end{array}$ & $\begin{array}{l}\hat{0} \\
\dot{0} \\
\text { p) }\end{array}$ & $\begin{array}{l}8 \\
\text { ¿ें } \\
\text { pे }\end{array}$ \\
\hline & $\simeq$ & $\mathfrak{K}$ & ㄴo & 음 & № \\
\hline & $\varangle$ & $\stackrel{\infty}{+}$ & F & \% & $\stackrel{\infty}{+\infty}$ \\
\hline$\underset{1=1}{E}$ & $\varangle$ & $\begin{array}{l}\infty \\
\text { ஜें } \\
\text { in }\end{array}$ & $\begin{array}{l}\text { o } \\
\text { ஜे } \\
\text { in }\end{array}$ & 今ે & ถิ \\
\hline \multirow{3}{*}{$\underbrace{\underline{\underline{y}}}_{\vec{\sigma}}$} & 응 & 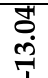 & $\begin{array}{l}\text { Sू } \\
\text { ஸี }\end{array}$ & $\begin{array}{l} \\
\dot{m} \\
\dot{m}\end{array}$ & \begin{tabular}{l}
$\widehat{T}$ \\
İ \\
\multirow{7}{*}{}
\end{tabular} \\
\hline & $\simeq$ & $\stackrel{\infty}{\infty}$ & $\stackrel{m}{\infty}$ & $\underset{\infty}{\infty}$ & $\underset{\infty}{\infty}$ \\
\hline & $\varangle$ & 솟 & $\stackrel{\infty}{\not}$ & 솟 & 옷 \\
\hline \multirow{3}{*}{$\underset{\omega}{\widetilde{m}}$} & $\frac{0}{\circ}$ & กิ & กิ & กิ & $\stackrel{\widehat{S}}{\hat{S}}$ \\
\hline & $\underset{\cong}{\Xi}$ & ลี & สิ & สิ & สิ \\
\hline & $\varangle$ & $\stackrel{\vec{m}}{=}$ & $\stackrel{\vec{m}}{\vec{G}}$ & $\stackrel{\vec{m}}{\Rightarrow}$ & 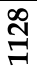 \\
\hline \multirow{3}{*}{$\begin{array}{l}\widehat{B} \\
\text { है } \\
\text { N }\end{array}$} & $\frac{8}{2}$ & $\vec{p}$ & $\stackrel{7}{+7}$ & $\vec{p}$ & تُ \\
\hline & $\simeq$ & $\stackrel{\infty}{\sigma}$ & $\stackrel{\infty}{\sigma}$ & $\stackrel{\infty}{\sigma}$ & $\stackrel{\infty}{\sigma}$ \\
\hline & $\varangle$ & นn & హ̆ & no & హ̆ \\
\hline \multirow{3}{*}{ 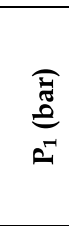 } & $\frac{9}{\circ}$ & ஜ̊ & ஜू & बे & gे \\
\hline & $\simeq$ & $\stackrel{m}{\stackrel{m}{\sigma}}$ & $\stackrel{m}{\text { ș }}$ & $\stackrel{m}{\circ}$ & \\
\hline & $\varangle$ & 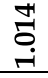 & 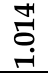 & & ن \\
\hline \multirow{3}{*}{$\underset{N}{\underset{N}{z}}$} & $\frac{0}{2}$ & ले & $\stackrel{\circ}{\dot{m}}$ & $\stackrel{\sim}{\infty}$ & $\stackrel{\circ}{\dot{m}}$ \\
\hline & $\simeq$ & চூ & ஜ็ & ઠั๋ & ถี \\
\hline & $\varangle$ & $\begin{array}{l}9 \\
10 \\
60\end{array}$ & $\begin{array}{l}0 \\
0 \\
0 \\
0\end{array}$ & $\begin{array}{l}\text { ô } \\
\text { ô } \\
0\end{array}$ & $\begin{array}{l}0 \\
0 \\
0 \\
0 \\
0\end{array}$ \\
\hline \multirow{3}{*}{$\underset{F}{\vec{y}}$} & $\frac{0}{\circ}$ & 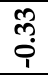 & $\begin{array}{l}30 \\
0 \\
0\end{array}$ & $\begin{array}{l}0 \\
\text { 웅 } \\
\text { i }\end{array}$ & $\begin{array}{l}\text { R̂ } \\
10 \\
\end{array}$ \\
\hline & $\simeq$ & ఫ్లి & ర్లి & ర్ల & ఫ్లి \\
\hline & $\varangle$ & নి & $\begin{array}{l}\overrightarrow{1} \\
\stackrel{\text { సे }}{ }\end{array}$ & নั่ & ลे \\
\hline อี & $\sum^{\breve{d}}$ & $\dot{ }$ & $\dot{N}$ & $\dot{m}$ & $+\vec{P}$ \\
\hline
\end{tabular}

\begin{tabular}{|c|c|c|c|c|c|}
\hline \multirow{3}{*}{$\begin{array}{l}\sum_{\mathrm{Z}} \\
\underline{\mathrm{Z}} \\
\mathbf{Z}\end{array}$} & $\frac{0}{0}$ & $\vec{i}$ & $\stackrel{\circ}{i}$ & $\stackrel{\text { qे }}{-}$ & $\stackrel{9}{\sim}$ \\
\hline & $\simeq$ & ర్రి & ర్రి & ర్లి & ర్లి \\
\hline & $\varangle$ & ర్లి & ఫ్రి & 뉴 & 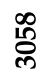 \\
\hline \multirow{3}{*}{$\overbrace{}^{\infty}$} & $\frac{0}{0}$ & $\stackrel{+}{+}$ & ָּ & மே. & $\stackrel{\circ}{\circ}$ \\
\hline & $\simeq$ & ని & సి & ని & ని \\
\hline & $\varangle$ & స్ & নి & : & ஜே \\
\hline$\stackrel{0}{\circ}$ & $\stackrel{\circ}{\simeq}$ & ヘิ & $\stackrel{\infty}{\stackrel{N}{~}}$ & $\stackrel{\infty}{\text { N }}$ & ๙ \\
\hline \multirow{3}{*}{$\leftarrow$} & $\frac{\theta}{2}$ & $\stackrel{10}{0}$ & $\stackrel{0}{0}$ & "ִ & ָ̦ \\
\hline & $\simeq$ & 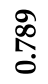 & 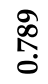 & $\begin{array}{l}\stackrel{2}{\circ} \\
\stackrel{0}{0}\end{array}$ &  \\
\hline & $\varangle$ & 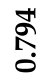 & 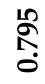 &  & $\begin{array}{l}\hat{\infty} \\
\stackrel{0}{0} \\
0\end{array}$ \\
\hline \multirow{3}{*}{$\stackrel{0}{\circ}$} & $\frac{0}{2}$ & 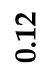 & $\frac{7}{3}$ & $\begin{array}{l}\text { i़े } \\
\text { iे }\end{array}$ & مُ \\
\hline & $\simeq$ & $\begin{array}{l}\text { J } \\
\infty \\
0\end{array}$ & $\begin{array}{l}\text { \& } \\
0 \\
0\end{array}$ & $\begin{array}{l}\text { J } \\
0 \\
0\end{array}$ & $\begin{array}{l}\text { J } \\
\infty \\
0\end{array}$ \\
\hline & $\varangle$ & $\begin{array}{l}\text { L̊ } \\
\text { \$0 } \\
0\end{array}$ & $\begin{array}{l}10 \\
10 \\
0 \\
0\end{array}$ & $\begin{array}{l}\stackrel{\infty}{\$} \\
0 \\
0\end{array}$ & $\begin{array}{l}0 \\
\infty \\
0 \\
0\end{array}$ \\
\hline$\underset{\sim}{\mathbb{y}}$ & $\varangle$ & $\begin{array}{l}0 \\
\text { ర̊ } \\
\text { மீ }\end{array}$ & 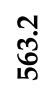 & ثึ & 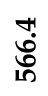 \\
\hline \multirow{3}{*}{ 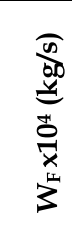 } & $\frac{2}{2}$ & $\stackrel{?}{\frac{m}{T}}$ & ָָ & ָָ & กี \\
\hline & $\simeq$ & ○ִ & 0. & فํ. & ○. \\
\hline & $\varangle$ & ๙̊ & $\vec{\sigma}$ & $\stackrel{R}{\stackrel{R}{*}}$ & $\hat{\mathscr{\sigma}}$ \\
\hline صّ & 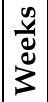 & $\dot{r}$ & d & $\dot{m}$ & मे \\
\hline
\end{tabular}

Table 1. (a) Values of the thermodynamics and performance parameters taken from AFAM IV, GT18, TYPE 13D 


\begin{tabular}{|c|c|c|c|c|c|c|c|c|}
\hline Weeks & \multicolumn{2}{|c|}{$\frac{\Delta T_{3}}{T_{3}}$} & \multicolumn{2}{|c|}{$\frac{\Delta N}{N}$} & \multicolumn{2}{|c|}{$\frac{\Delta \eta_{c}}{\eta_{c}}$} & \multicolumn{2}{|r|}{$\frac{\Delta \Gamma_{c}}{\Gamma_{c}}$} \\
\hline $\begin{array}{l}1 . \\
2 . \\
3 . \\
4 .\end{array}$ & $\begin{array}{l}a_{1} \\
a_{5} \\
a_{9} \\
a_{13}\end{array}$ & $\begin{array}{l}-0.075 \\
-0.075 \\
-0.075 \\
-0.078\end{array}$ & $\begin{array}{l}\mathbf{a}_{2} \\
\mathbf{a}_{6} \\
\mathbf{a}_{10} \\
\mathbf{a}_{14}\end{array}$ & $\begin{array}{l}0.021 \\
0.020 \\
0.019 \\
0.019\end{array}$ & $\begin{array}{l}\mathbf{a}_{3} \\
\mathbf{a}_{7} \\
\mathbf{a}_{11} \\
\mathbf{a}_{15}\end{array}$ & $\begin{array}{l}0.0012 \\
0.0012 \\
-0.0059 \\
0.0107\end{array}$ & $\begin{array}{l}\mathbf{a}_{4} \\
\mathbf{a}_{8} \\
\mathbf{a}_{12} \\
\mathbf{a}_{16}\end{array}$ & $\begin{array}{l}-0.044 \\
-0.017 \\
-0.051 \\
0.000\end{array}$ \\
\hline
\end{tabular}

Table 1. (b) Values of the ccoefficients

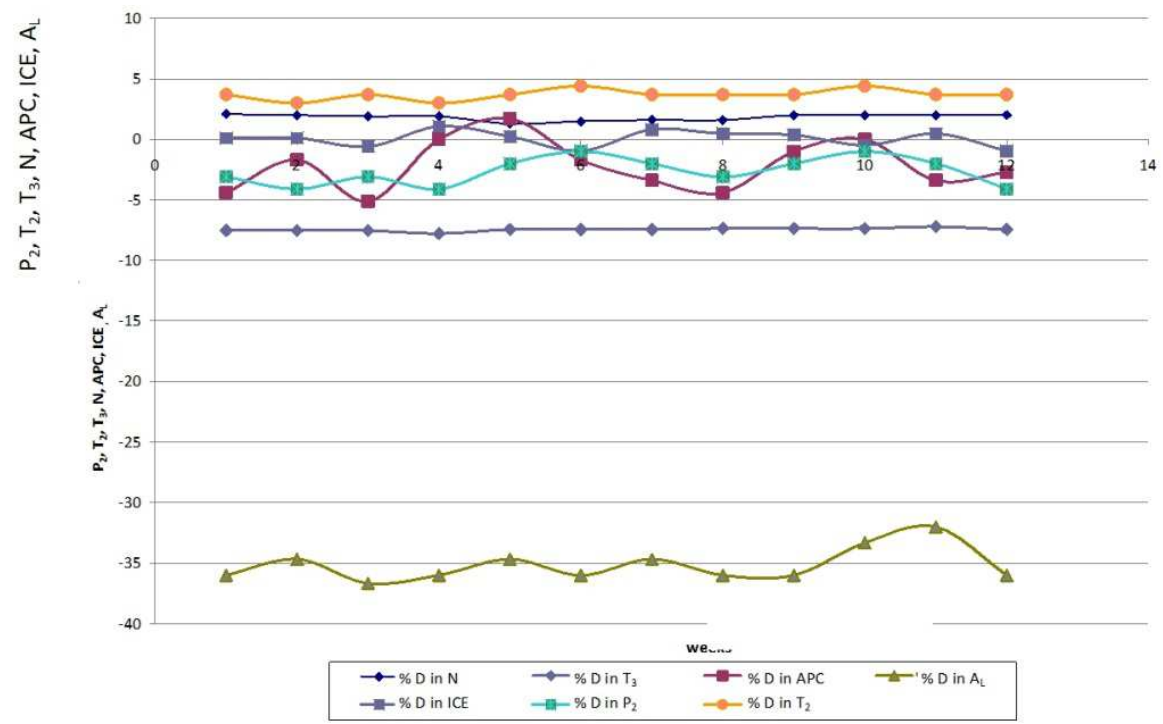

Date, Weeks

Fig. 4. Percentage deviation in $\mathrm{P}_{2}, \mathrm{~T}_{2}, \mathrm{~T}_{3}, \mathrm{~N}, \mathrm{APC}, \mathrm{ICE}$ and $\mathrm{A}_{\mathrm{L}}$ against date (in weeks) 


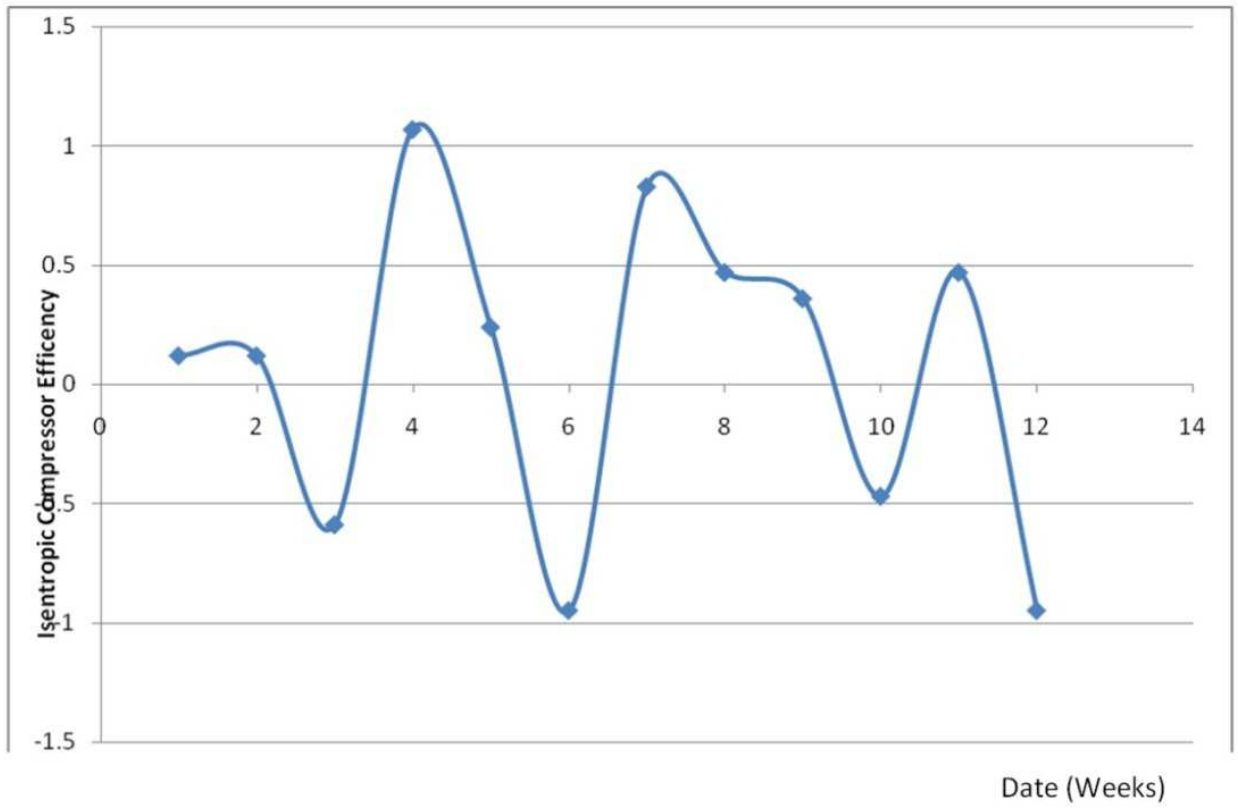

Fig. 5. Percentage deviation of ICE against date (in weeks)

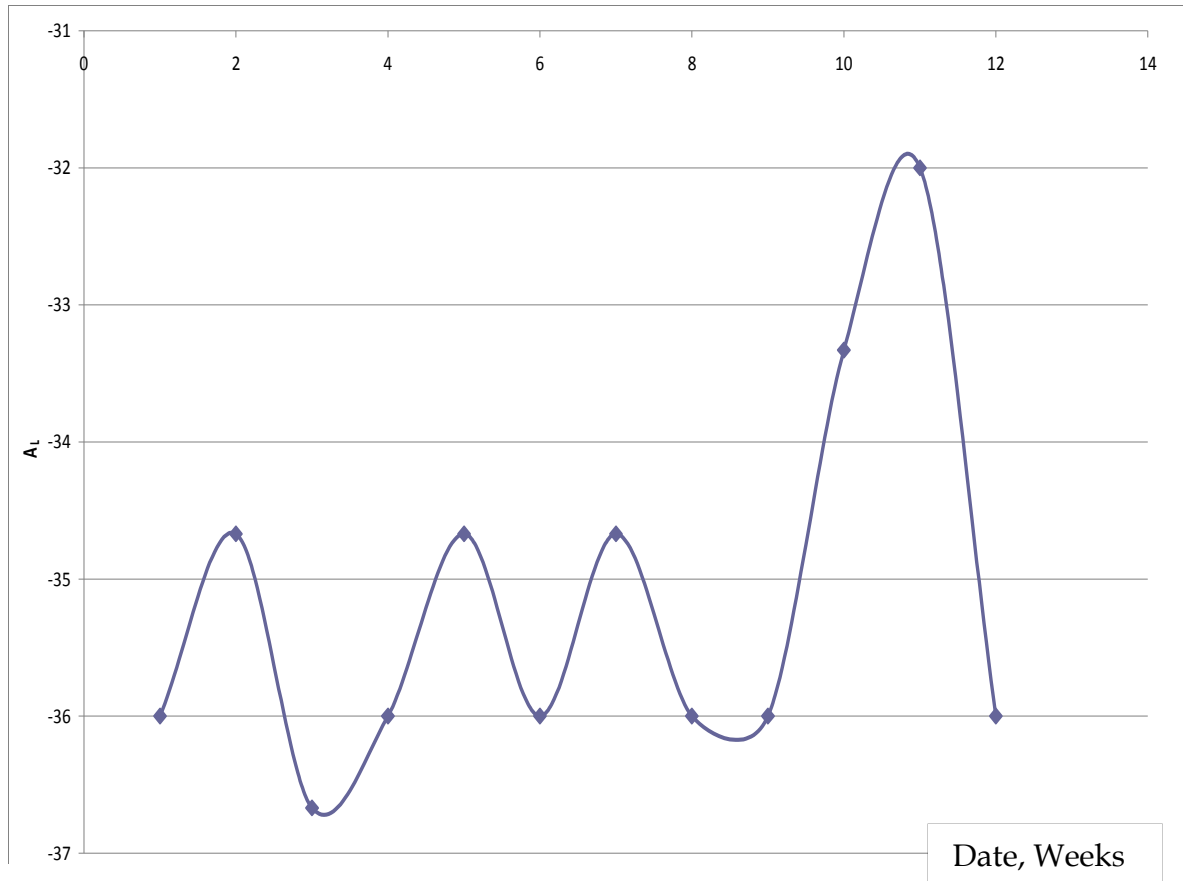

Fig. 6. Percentage deviation in $A_{L}$ against date (in weeks) 


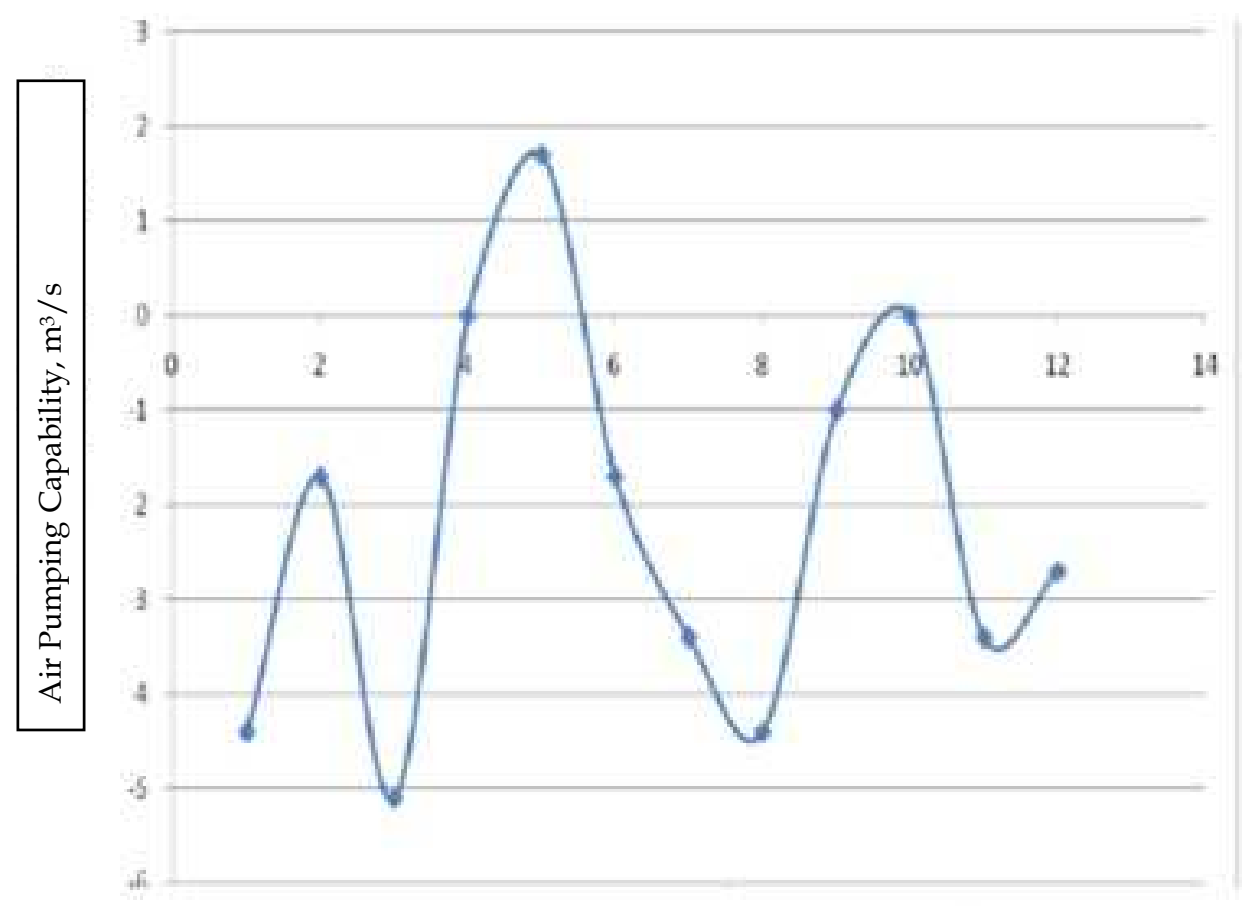

Date, Weeks

Fig. 7. Percentage deviation in APC against date (in weeks) 


\section{Conclusion}

In this work, the MVMMs of a test engine was generated by taking advantage of the gas path analysis. The models were applied to develop the software "THAPCOM". This software thus enabled diagnosis and prognosis to be carried out on the equipment through the comparison between the actual and reference values of the engine. Advantage was brought to bear using previous works done on adaptive modelling of various aspects of GT health monitoring. The software when installed in a system interface of the GT enabled the proactive monitoring of the engine's health. The software gives an alarm signal whenever a set limit is near the dependent or independent parameters. This alarm signal allows the operator to carry out maintenance before the equipment fails.

\section{Acknowledgements}

The authors are highly grateful for the contributions of the staff of Afam Thermal Station where the data and experimentations were conducted. They are Engrs. D. U. Obiagazie, L. Ofurum, M. U. Ukpai, K. Kalio.

\section{References}

Alexious, A and Mathioudakis, K(2006) Gas Turbine Engine Performance Model Application Using an Objective Oriented Simulation Tool, ASME Turbo-Expo 2006, Power for Land, Sea and Air, The Barcelona, Spain, May 8-11. Available at http://www.137.205.176.10/content/engine/sp2-asme-turbo-2006-alexious.pdf

Aretakis, N., Roumeliotic, I and Mathioudakis, K(2010) Performance Model "Zooming" for In-Depth Component Fault Diagonsis, Proceedings of ASME Turbo-Expo 2010, GT2010-23262, Glasgow-Scotland, UK, pp. 1-2

Aretakis, N., Mathioudakis, K and Stamatis, A.(2003) Non- Linear Engine Component Fault Diagnosis From a Limited Number of Measurements Using a Combinational Approach, Journal of Engineering for Gas Turbines and Power, Vol. 125, Issue 3, pp. 642-650

Baker, W.E(1991) Similarity Methods in Engineering Dynamics:Theory and Practice of Scale Modeling(Revised Edition), ISBN :0-444-88156-5, Elsevier Science Publishers B.V, Amsterdam, The Netherlands, pp. 7-18

Bell, D.R., (2003): The Hidden Cost of Downtime: Strategies for Improving Return on Assets, Smart Signal Co. USA. pp. 1-4

Bergman,J.M., Boot, P and Woud, K. K(1993) Condition Monitoring of Diesel Engines with Component Models, Paper 17 International Conference on Marine Environnmental and Safety (ICMES) 93, Marine Management(Holdings) Limited,, The Netherlands.

Bently, D.E., Hatch, C.T., and Grisson, B., (2002): Fundamentals of Rotating Machinery Diagnostics, Bently Pressurized Bearing Press Co., Canada. 1st Print, p. 288

Brun, K., and Kurz, R., (2007): Gas Turbine Tutorial - Maintenance and Operating Practice Effects on Degradation and life, Proceedings of the Thirty-sixth Turbo Machinery Symposium, pp. 1-2. 
www.igu.org/html/wgc2009/papers/docs/wgcFinal00076.pdf

Doel, D(1994) A Gas Path Analysis Toolfor Commercial Jet Engines, Transaction of ASME Journal. of Engineering for Gas Turbines and Power, Vol.116, pp. 82-89

Donald, L.S., Volponi,A.J., Bird,J., Davison, C and Verson, R.E(2008) Benchmarking Gas Path Diagnostic Methods : Public Approach, IGTI/ASME Turbo-Expo 2008, GT200851360, Berlin- Germany, p.2.

Erbes, M. R., and Palmer, C. A., (1994): Simulation Mehtods used to Analyse the Performance of the GE E6541B Gas Turbine utilizing Low Heating Value Fuels. ASME Cogen Turbo Power, Portland Oregen. pp. 1 - 2.

Erbes, M. R., Palmer, C. A., and Pechti, P. A., (1993): Gas Cycle Performance Analysis of the LM2500 Gas Turbine utilizing Low Heating Values. IGTI - vol. 8. ASME Cogen Turbo Power. pp .1-2.

Fast, M., Assadi, M., Pike, A and Breuhaus, P(2009) Different Conditon Monitoing Models for Gas Turbines by Means of Artifical Neural Networks, IGTI/ASME TurboExpo2009, GT2009-59364, Orlando- Florida, USA, p11

Guy, K. R., (1995): Turbine Generator Monitoring and Analysis, Mini-Course Notes, Proceedings of Vibration Institute. $\mathrm{p} 2$. www.sandv.com/downloads/0703puse.pdf

Kamboukas, P and Mathioudakis, K(2005) Comparison of Linear and Non- linear of Gas Turbine Performance Diagnostics, Journal of Engineering for Gas Turbines and Power, Vol.127, Issue 1, pp...49-56.

Loboda, I(2008) Trustworthiness Problem of Gas Turbine Parametric Diagnosing, 5th IEAC Symposium of Technical and Safe Processes, 2003, Washinton DC, USA, p.8.

Loboda, I and Yepifanov, S(2010) A mixed Data-Driven and Model-Based Fault Classification For Gas Turbines Diagnosis, Proceedings of ASME Turbo-Expo 2010, Paper No. GT2010-23075, Glasgow- Scotland, UK, pp1-2.

Maria, A. (1997): Introduction to Modeling and simulation, Proceedings of the 1997 Winter Simulation Conference (ed. S. Androdothi, K. J. Healy, D. H. Withers and B. L. Nelson), pp 7-9.

Ogbonnaya E. A., (2004a): Modeling Vibration - Based Faults in Rotor Shaft of a Gas Turbine, Ph.D Thesis, Dept. of Mar. Engrg., RSUST, Nkpolu Port Harcourt, Nigeria. pp 82160.

Ogbonnaya, E. A., (2004b): Thermodynamics of Steam and Gas Turbines, $1^{\text {st }}$ edition, Oru's Press Ltd, Port Harcourt. pp 4-5.

Ogbonnaya, E. A., and Koumako, K.E.E., (2006): Basic Automatic Control, $1^{\text {st }}$ edition, King Jovic Int'l. Publisher Port Harcourt. Pp 114-115.

Ogbonnaya E.A., (1998): Condition Monitoring of a Diesel Engine for Electricity Generation, M-Tech. Thesis, Dept. of Mar. Engrg. RSUST, Port Harcourt, Nigeria. pp 42-43.

Ogbonnaya, E.A., (2009): Diagnosing and Prognosing Gas Turbine Rotor Shaft Faults Using "The MICE", Proceedings of ASME Turbo Expo, GT 2009-59450, Orlando, Florida, USA . pp 1-6. 
Ogbonnaya E.A and Theophilus-Johnson, K(2010) Use of Multiple Variable Mathmatical Method for Effective Condition Monitoring of Gas Turbines, Proceedings of ASME Turbo- Expo GT 2010-22568,Glasgow, Scotland, June 14-18. 2010,

Ogbonnaya, E.A., Theophilus-Johnson, K.,Ugwu, H.U and Orji, C.U(2010) Component Model-Based Condition Monitoring of a Gas Turbine, ARPN Journal of Engineering and Applied Sciences, Vol.5, No.3 March. Available at: www.arpnjournal.com.

Ogbonnaya E.A and Theophilus-Johnson, K(2011) Optimizing Gas Turbine Rotor Shaft fault Detection, Identification and Analysis for Effective Condition Monitoring, Journal of Emerging Trends in Engineering and Applied Sciences (JETEAS) 2(1),11-17 Copright Scholarlink Research Instite Journals (ISSN:2141-7016). Available at:.

http://www.jeteas.scholarlinkresearch.org and

http://www.scholarlinkresearch.org.

Pussey, H. C., (2007): Turbo machinery Condition Monitoring and Failure Prognosis, Shock and Vibration Information Analysis Centre/Hi-Test Laboratories, Proceedings of Institute of Vibration, Winchester, Virginia.. pp 2-10.

Rieger, N.F., McCosky, T.H and Davey, R.P(1990) The High Cost of Failure of Rotating Equipment, Proceedings of the 44th Conference of Machinery Failure Prevention Group (MFPG), Vibration Institute, pp.2-3.

Roemer, M. J. and Kacprzynski, G.J(2000) Advanced Diagnosyic and Prognostic for Gas Turbine Risk Assessment, Proceedings of ASME Turbo Expo GT2000, gt 2000-30, Germany. p.10.

Romesis, C and Mathioudakis, K. (2003) Setting up of a Probabilistic Neural Network for Senor Fault Detection Including Operation with Component Fault, Journal Of Engineering for Gas Turbines and Power, 125, pp.634-641.

Schneider, E.., Demircioglu, S.; Franco, S., and Therkorn, D., (2009): Analysis of Compressor On-Line Washing to Optimize Gas Turbine Power Plant Performance, Proceedings of ASME Turbo Expo 2009, GT 2009-59356, Orlando, Florida, USA. pp 1-4.

Stamatis, A., Mathioudakis, K., Berios, G and Papailiou, K(1991) Jet Engine Fault Detection with Discrete Operating Points Using Gas Path Analysis, Journal of Propulsion and Power, Vol.7, No.6, pp.2-3.

Stamatis, A., Mathioudakis, K., Ruis, J and Curnock, B (2001) Real-Time Engine Model Implementation for Adaptive Control and Performance Monitoring of Large Turbo-fans, ASME 2001-GT-362. Available at: http://www.ase.aec.nasa.gov/projects/ishem/paper/vdponi_ac_prop.doc.

Uhumnwangho, R.; Ofodu, J.C., and Emiri, U. V., (2003): Performance Evaluation of a Gas Turbine Engine, Univ. of Port Harcourt, Nigeria. Nigerian Journal of Engineering Research and Development, Vol. 2, No.1. pp 9-20.

Urban, L.A and Volponi, A.J (1992) Mathematical Methods Of Relative Engine Performance Diagnostics, SAE Transactions, Vol. 101, Journal of Aerospace, Technical paper 922048. pp.4-5.

Volponi, A.J (1994) Sensor Error Compensation in Engine Performance Diagnostics, ASME Paper, GT1994-58. 
Volponi, A.J.,Depold, H. And Ganguli, R.(2003) The Use of Kalman Filter and Neural Network Methodologies in Gas Turbine Performance Diagnostics: A Comparative Study, Journal of Engineering for Gas Turbines and Power, Vol. 125, Issue 4, pp917-924. 


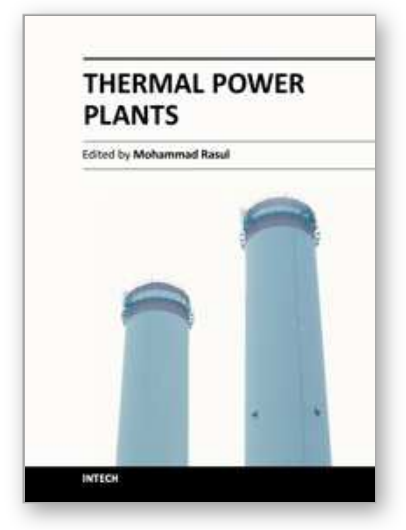

\author{
Thermal Power Plants \\ Edited by Dr. Mohammad Rasul
}

ISBN 978-953-307-952-3

Hard cover, 266 pages

Publisher InTech

Published online 13, January, 2012

Published in print edition January, 2012

Thermal power plants are one of the most important process industries for engineering professionals. Over the past few decades, the power sector has been facing a number of critical issues. However, the most fundamental challenge is meeting the growing power demand in sustainable and efficient ways. Practicing power plant engineers not only look after operation and maintenance of the plant, but also look after a range of activities, including research and development, starting from power generation, to environmental assessment of power plants. The book Thermal Power Plants covers features, operational issues, advantages, and limitations of power plants, as well as benefits of renewable power generation. It also introduces thermal performance analysis, fuel combustion issues, performance monitoring and modelling, plants health monitoring, including component fault diagnosis and prognosis, functional analysis, economics of plant operation and maintenance, and environmental aspects. This book addresses several issues related to both coal fired and gas turbine power plants. The book is suitable for both undergraduate and research for higher degree students, and of course, for practicing power plant engineers.

\title{
How to reference
}

In order to correctly reference this scholarly work, feel free to copy and paste the following:

E. A. Ogbonnaya, K. T. Johnson, H. U. Ugwu, C. A. N. Johnson and Barugu Peter Forsman (2012). Adaptive Gas Path Modeling in Gas Turbine Health Monitoring, Thermal Power Plants, Dr. Mohammad Rasul (Ed.), ISBN: 978-953-307-952-3, InTech, Available from: http://www.intechopen.com/books/thermal-powerplants/adaptive-gas-path-modeling-in-gas-turbine-health-monitoring

\section{INTECH}

open science | open minds

\section{InTech Europe}

University Campus STeP Ri

Slavka Krautzeka 83/A

51000 Rijeka, Croatia

Phone: +385 (51) 770447

Fax: +385 (51) 686166

www.intechopen.com

\section{InTech China}

Unit 405, Office Block, Hotel Equatorial Shanghai

No.65, Yan An Road (West), Shanghai, 200040, China 中国上海市延安西路65号上海国际贵都大饭店办公楼 405 单元

Phone: +86-21-62489820

Fax: +86-21-62489821 
(C) 2012 The Author(s). Licensee IntechOpen. This is an open access article distributed under the terms of the Creative Commons Attribution 3.0 License, which permits unrestricted use, distribution, and reproduction in any medium, provided the original work is properly cited. 